Biofuels and the politics of land-use change: Tracing the interactions of discourse and place in European policy-making

James R Palmer

Keble College, University of Oxford, Oxford, $\mathrm{OX}_{1}{ }_{3} \mathrm{PG}$

james.palmer@keble.ox.ac.uk

\title{
Acknowledgements
}

This research was funded by the Economic and Social Research Council (Grant Number: ES/GO13195/1), and would have been impossible without the generous participation of my interviewees, for which I am extremely grateful. Special thanks go to Professor Susan Owens of the Department of Geography in Cambridge for her advice on an early draft, and to Eszter Kovacs for introducing me to the work of Merje Kuus. The comments of three anonymous referees were also immensely helpful. Any remaining errors are entirely the author's own. 


\section{Biofuels and the politics of land-use change: Tracing the interactions of discourse and place in the European policy-making}

\section{Abstract}

Whilst transport biofuels have enjoyed strong political support in Europe for much of the past decade, concerns over their full impacts have an almost equally long history. Since 2008, these concerns have centred most intently upon the land-use change impacts of biofuel production, whereby increased demand for biofuels leads non-agricultural landscapes to be converted - either directly or indirectly - into agricultural ones.

Amongst other things, biofuel-driven land-use change might potentially lead to significant emissions of Greenhouse Gases (GHG), losses of biodiversity, reduced ecosystem resilience, degradation of soil and water resources, declines in regional food security, or even land rights infringements through so-called 'land-grabbing'. Political debates surrounding biofuel-driven land-use change in Europe have historically been restricted, however, to considerations of technical modelling work addressing the GHG emissions that might result from this process, thereby ignoring a wide range of alternative issues.

Adopting a discursive-institutionalist perspective (Schmidt, 2008), this paper scrutinises two inter-related sets of dynamics pertaining to the handling of this political issue in Europe. First, it examines how the specific bureaucratic context of Brussels has itself been constitutive of the discursive practices used by policymakers to establish and retain control of the prevailing political conception of biofuel-driven land-use change. Second, it examines how these practices have inevitably led to what Scott (1998: 11) terms a "narrowing of vision" in policymakers' approach to this problem, with concomitant implications for the role occupied by conceptions of 'place' in the policy process. In both instances, the argument is made that such interactions exclude critical perspectives on what is at stake in the drive for biofuels from relevant policy-making procedures altogether.

In light of these conclusions, the paper contends that future geographical analyses of environmental policy-making writ large should pay greater attention to the interactions of discourse and place, particularly if they are to better understand the precise mechanisms through which political controversy is ultimately managed and settled in modern democratic contexts today.

\section{Keywords}

Biofuels, land-use change, discourse, place, environmental policy-making 


\section{Introduction}

Biofuels ${ }^{1}$ can be defined succinctly as "renewable fuels derived from biological feedstocks" (Koh and Ghazoul, 2008: 2451). On the surface at least, they appear to constitute a carbonneutral energy source, since upon combustion they release into the atmosphere only that carbon which was sequestered during their growth as biological matter. In the specific context of the road transport sector, biofuels' political appeal can be said to derive from three distinct sources. First, as a technology that is compatible with present infrastructures, biofuels have the attraction of being able to reduce transport greenhouse gas (GHG) emissions immediately ${ }^{2}$. Secondly, by diversifying Europe's fuel supply, biofuels will arguably also serve to enhance energy security, primarily by reducing motorists' dependence upon oil that can be expensive, and which is often sourced from politically volatile regions. Finally, since recent rises in global demand for biofuels have effectively created an entirely new market for the agricultural produce of both developed and developing economies ${ }^{3}$, many argue that biofuels will also serve to indirectly boost rural incomes and employment. In anticipation of all of these alleged benefits, European policy-makers passed a Biofuels Directive in 2003 (EC, 2003), instituting relatively modest, non-binding targets for biofuel consumption across the European Union (EU). With the passing of the more recent Renewable Energy Directive (RED) in 2009 (EC, 2009a), these targets became mandatory, and

\footnotetext{
${ }^{1}$ Whilst biofuels can have stationary and mobile applications, and may theoretically take solid, liquid or gaseous form, this paper deploys the term exclusively to refer to liquid, hydrocarbon-based biofuels whose primary purpose is to directly replace petrol or diesel used in the road transport sector.

${ }^{2}$ Modern internal combustion engines can function almost entirely unhindered upon a blend of fossil and non-fossil hydrocarbons (i.e. petrol with a small amount of bioethanol or diesel with a small amount of biodiesel).

3 The majority of biofuels consumed by motorists in the European Union today are derived from staple food crops such as wheat, oilseed rape, sugar cane, soy and oil palm, and can therefore be obtained from any location where these cultivars are already grown.
} 
were increased to stipulate that $10 \%$ of road fuel, as measured by energy content, should be derived from renewable sources, including but not limited to biofuels ${ }^{4}$, by the year 2020 .

Despite their multiple attractions though, biofuels are not without problems. Various doubts surrounding the authenticity of their environmental and socio-economic credentials (Bailey, 2008; FOE, 2007; Kutas et al., 2007; Royal Society, 2008; RSPB, 2008), as well as concerns about their potential impact upon food prices and food security (Kelly, 2012; Mitchell, 20o8; The Times, 2008), have run high for a number of years (for analyses of political debates surrounding these issues in the UK, see Dunlop, 2010; Palmer, 2010). Couched within these broad tensions, the issue of biofuel-driven land-use change has proven especially controversial. Whether induced directly or indirectly, land-use change raises significant concerns because it has the potential to exert deleterious effects both environmentally (e.g. through greenhouse gas (GHG) emissions and biodiversity loss) and socially (e.g. through land rights infringements and local and regional food security impacts) (see Palmer, 2012: 497-499 for an overview). In the specific case of indirect land-use change (ILUC), moreover, such complexity is compounded by the impossibility of directly observing the process, since it propagates through global agricultural markets. Indeed, for this very reason, a European Commission report itself concedes that estimates of impacts resulting from ILUC "can never be validated" (EC, 2010: 6).

Against this backdrop of profound complexity and uncertainty, the present paper seeks to analyse political processes through which biofuel-driven land-use change has been operationalised and made 'knowable' by policy-makers at the European level, especially since

\footnotetext{
${ }^{4}$ Despite increasingly rapid developments in alternative fields, for example in the electric vehicle industry, it is widely expected that the majority of this $10 \%$ target (between approximately $6 \%$ and 9.2\%) will be met in 2020 through biofuel blending (Al-Riffai et al., 2010; Bowyer, 2010).
} 
2008. Drawing from an analysis of around thirty semi-structured interviews, and documentary data, it adopts a discursive-institutionalist perspective (Schmidt, 20o8) to scrutinise two inter-related sets of dynamics. First, it examines how the specific bureaucratic context of Brussels is itself constitutive of the discursive practices used by policy-makers to retain control over the prevailing conception of biofuel-driven land-use change in Europe. Second, it examines how such discursive practices have inevitably led to what Scott (1998: 11) would term a "narrowing of vision" in policy-makers' approach to this problem, with concomitant implications for the role occupied by conceptions of 'place' in the policy process. Following Kuus (2011: 2), the paper can therefore be thought of as aiming to investigate both "how bureaucracies are socially embedded in particular places, and conversely, how they constitute places". By thus conceiving of place as a "space invested with meaning in the context of power" (Cresswell, 2004: 12), the analysis hopes to provide valuable insights into the actual mechanisms through which power is ultimately secured and exercised in Brussels.

The remainder of the paper is structured as follows. In the next section, the paper's overall theoretical approach of discursive-institutionalism, which emphasises ideas and discourse as significant causal variables in the policy-making process, is outlined. Subsequently, the discussion moves on to outline in greater detail the complexities and uncertainties that are inherent to the issue of biofuel-driven land-use change. The paper's main analytical section then follows, examining the two inter-related sets of processes referred to above. Finally, having set out its main claims, the paper concludes by reflecting on the theoretical implications of its findings, suggesting ways forward for future geographical research addressing European policy-making processes, especially in the context of problems characterised by similarly high levels of complexity and uncertainty. 


\section{Making the case for discursive institutionalism}

For Schmidt and Radaelli (2004), conventional analyses of the European politics and policymaking have tended to emphasise four distinct categories of variable in seeking to explain policy change. These are "the policy problems that establish the need for policy change", "the policy legacies that may or may not 'fit' proposed policy solutions", "the policy preferences that may or may not change in the light of problems and proposed solutions", and finally "the political institutional capacity of actors to respond to the problems through new policy initiatives even if these reverse policy legacies and preferences" (ibid: 186). The approach subscribed to in this paper, discursive institutionalism, does not dismiss such approaches, but rather seeks to build upon them by paying detailed attention to the role of ideas and discourse, as a fifth distinct category of variable, in the European policy-making process (cf. Schmidt, 2008, 2011).

Discourse can be succinctly defined as "an ensemble of ideas, concepts and categorisations through which meaning is given to social and physical phenomena, and which is produced and reproduced through an identifiable set of practices" (Hajer, 1995: 44). This definition is useful in that it reveals discourse to be both a thing and an $a c t^{5}$ (see also Milton, 1993). Specifically, as "a set of ideas, concepts and categorisations", discourse helps to determine what can and cannot be said in debates about particular policy issues, thereby impacting on the extent to which knowledge claims of various types will be viewed as credible and legitimate. As "a set of identifiable practices" meanwhile, discursive activity involves not only the persuasive communication of ideas, concepts and categorisations that are central to a

\footnotetext{
${ }^{5}$ Indeed, it also sits very comfortably with Schmidt's (2008: 321) definition of discourse as serving "not just to represent ideas but also to exchange them through interactive processes."
} 
discourse, but also strategic action designed to prevent competing discourses from being articulated or heard within relevant political discussions.

To overlook the roles of discourse and discursive activity in the policy-making process is arguably a grave oversight because, as cognitive variables, they possess significant potential to alter actors' perceptions of policy problems, legacies and preferences, and thereby to alter their political institutional capacity to effect policy change. This insight is not especially new; Heclo (1974: 4) famously remarked in his seminal work on the social politics of Britain and Sweden that policy is not self-evident, but instead "acquires meaning because an observer perceives and interprets a course of action amid the confusions of a complex world." More recently, Hajer (2005: 300) has argued that "language has the capacity to make politics, to create signs and symbols that can shift power-balances and impact on institutions and policymaking.”

Despite the enthusiasm with which cognitive variables are emphasised under discursive institutionalism however, it is also important not to assume that the approach mounts explanations for policy change that rely exclusively upon them. Indeed, as Schmidt and Radaelli (2004: 184) make clear, to fully understand the influence of discourse in policymaking, it "must be set in institutional context." Similarly, for Hajer (2005: 300), without simultaneously mapping the precise "socio-historical conditions" in which discursive statements and utterances are produced and received, even the most forensic assessment of those statements will be of little use in understanding the extent to which they have actually impacted on processes underpinning policy change. By examining the ways in which Brussels, as a place-specific bureaucratic setting, is fundamentally constitutive of both discourse and discursive activity relating to the issue of biofuel-driven land-use change, the 
present paper effectively seeks to illuminate one major, but often overlooked aspect of these 'socio-historical' conditions.

In taking this overall approach, the paper of course builds upon theories of policy-making that already recognise place as an important variable, such as Baumgartner and Jones' (1991, 2009) 'punctuated equilibrium' theory. Under this approach, patterns of policy intertia or change are argued to emerge from strategic action by political actors on two fronts, firstly aiming to "control the prevailing image" of a given problem, and secondly aiming to "alter the roster of participants who are involved in [relevant debates] by seeking out the most favourable venue for the consideration of their issues" (Baumgartner and Jones, 1991: 1045). Here, control over specific places or 'venues' effectively constitutes a tool of 'non-decision making', in which actors limit the scope of actual decision making to 'safe' issues "by manipulating... dominant community values, myths and political institutions and procedures" (Bachrach and Baratz, 1963: 632). Yet the paper also delves more deeply into these dynamics by asking what is specific about the places and venues of policy-making in Brussels, and indeed how these specificities impact on observed policy-making outcomes. As Kuus (2011: 5) remarks, "amidst careful reviews of treaty stipulations, management charts, and accounts of inter-state negotiations, one gets little sense of the social textures of [Brussels'] European Quarter." Yet for those in human geography and related disciplines who ask 'how' questions relating to politics, such social textures, comprised of spatially embedded day-today practices, modes of comportment, codes of dress, and social norms, are argued here to represent a critically important site of empirical enquiry.

To summarise, this paper subscribes to a theoretical approach under which discourse is recognised to contribute an additional layer of complexity to policy-making processes; one 
that sits on top of the other causal variables identified by Schmidt and Radaelli (2004) above, and which must be analysed within a context of broader socio-historical conditions of which specific bureaucratic settings are a fundamental component (Hajer, 2005). Before moving on to undertake its main analytical tasks however, the paper first turns its attention briefly to the complexities and uncertainties that are inherent to biofuel-driven land-use change, in a bid to elucidate their characteristics in greater detail.

\section{Biofuel-driven land-use change - An intractable regulatory issue?}

Biofuel-driven land-use change comprises the conversion of non-agricultural landscapes into agricultural ones. More specifically, indirect land-use change occurs when biofuel production displaces pre-existing agricultural activity into new geographical territory, whilst direct landuse change occurs when biofuels are grown on land that has been converted especially for this purpose (figure one).

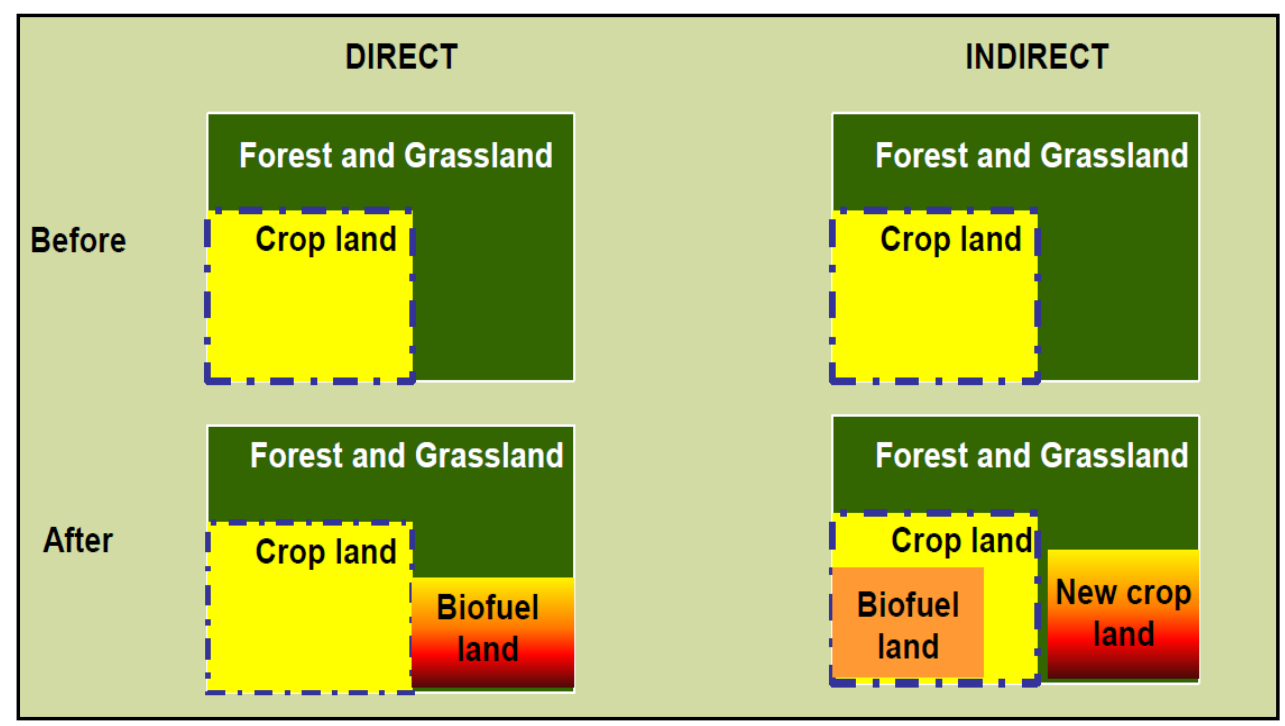

Figure 1: Diagram illustrating the distinction between direct and indirect land-use change (Source: Woods, 2009). 
Whether it is occasioned directly or indirectly however, land-use change can legitimately be associated with a diverse range of risks, as outlined in table one.

\begin{tabular}{|c|c|c|}
\hline Risk & Classification & Examples of populations or groups at risk \\
\hline $\begin{array}{l}\text { Climate change } \\
\text { exacerbation }\end{array}$ & Environmental & - Entire global population \\
\hline Biodiversity loss & Environmental & $\begin{array}{l}\text { - Vulnerable plant and animal species in } \\
\text { locations where land-use change occurs } \\
\text { - Human populations dependent upon } \\
\text { ecosystem services previously emanating } \\
\text { from landscapes converted to agriculture }\end{array}$ \\
\hline Food insecurity & Socio-economic & $\begin{array}{l}\text { Populations living in locations where } \\
\text { indigenous food production declines } \\
\text { owing to land-use change }\end{array}$ \\
\hline $\begin{array}{l}\text { Land rights } \\
\text { infringements }\end{array}$ & Socio-economic & $\begin{array}{l}\text { - Populations whose land rights are not } \\
\text { formally articulated or who lack the } \\
\text { resources to defend those rights }\end{array}$ \\
\hline $\begin{array}{l}\text { Soil and water } \\
\text { resource degradation } \\
\text { and depletion }\end{array}$ & $\begin{array}{l}\text { Socio-economic and } \\
\text { environmental }\end{array}$ & $\begin{array}{c}\text { Ecosystems dependent upon clean and } \\
\text { plentiful water supply (e.g. rivers) } \\
\text { - Human populations dependent upon local } \\
\text { water resources that are scarce and/or } \\
\text { vulnerable to contamination }\end{array}$ \\
\hline
\end{tabular}

Table 1: Risks that can legitimately be associated with biofuel-driven land-use change

Crucially, these risks, ranging from climate change exacerbation and losses of biodiversity through to land rights infringements and decreased food security, are sufficiently heterogeneous to engage stakeholders with interests in policy fields as diverse as agriculture, energy, environment, development and trade. It is perhaps unsurprising therefore to find that the issue of biofuel-driven land-use change has engendered what might be termed "intractable policy controversy" (Schön and Rein, 1994), at least at the European level. Consequently, from the perspective of some socially-oriented non-governmental organisations (NGOs) and academics, the potential impacts of land-use change upon land rights and regional food security constitute a worrying moral issue which merits greater political attention (Kelly, 2012; Matondi et al., 2011; Mawdsley, 2012; Rice, 2010; Vermeulen 
and Cotula, 2010). By contrast, for more environmentally oriented groups, the potential impacts that land-use change might exert upon biodiversity and global climate change are of greater concern (Birdlife et al., 2010; Clift and Mulugetta, 2007; Danielsen et al., 2009; Fargione et al., 2008; Greenpeace, 2007; Searchinger et al., 2008).

In light of this complexity, a former chief scientific adviser to the UK's Department for Environment, Food and Rural Affairs (DEFRA) argues that any legitimate political response to biofuel-driven land-use change should attempt at least a passing assessment of each potential set of impacts that the process might engender:

'[We] should look effectively at [whether there are] other impacts of land use change. And that means are there effects on social issues? Will it itself have an impact on food prices? Could it lead to the displacement of people? What are the implications for biodiversity and ecosystem services? We should at least look at it, and then governments can make a decision.' (Interview, ex-DEFRA chief scientific adviser, $18^{\text {th }}$ June 2010).

Crucially, such a thoroughgoing assessment of the full impacts of biofuel-driven land-use change can only be carried out in the presence of geographical knowledge about the placespecific character of those changes. This is because the magnitude of all of the impacts listed in table one will inevitably be mediated by local environmental and socio-economic conditions (pertaining for instance to the type of soil and vegetation that is present in a region, local climatic conditions, the level of development of local populations, or the nature of regional food markets). As one European Commission official therefore explained:

'It's hard enough to try and say what the GHG impacts of [land-use change] will be, but when you come onto something like biodiversity the problem is it matters where exactly the land is being converted.' (Interview, European Commission Official, $15^{\text {th }}$ March 2011, emphasis added)

Of course, in the case of indirect land-use change, which propagates through global agricultural markets, precise geographical knowledge of this kind cannot be obtained with 
full certainty, and must therefore be approximated using models. As the European Commission explained in a report published in late 2010:

'It will never be possible, looking forward, to say that the introduction of a biofuel policy will lead to the conversion of a particular, identified piece of land. It will never be possible, looking back, to say that the introduction of a biofuel policy was the cause of a particular, identified piece of land being converted' (DG Energy, 2010: 10).

The irresolvable uncertainties that ultimately characterise knowledge about the geographical footprint of biofuel-driven land-use change therefore pose serious problems for those who seek to determine the real impacts of this process on levels of environmental and social welfare in different parts of the world. Against this backdrop, the following section now moves on to examine discursive practices through which this complex problem has ultimately been rendered 'knowable' by European policy-makers, paying particular attention to their place-specific dimensions within the bureaucratic setting of Brussels.

\section{Bringing land-use change under control: Discursive activity, place and the Brussels 'bubble'}

Tracing the emergence of a discourse: Land-use change as a carbon accounting error

In seeking to examine the European Commission's attempts to render biofuel-driven landuse change 'knowable', it is useful to begin with an assessment of the problem's initial introduction onto the EU's political agenda. In official terms at least, the European Commission can be said to have conceived of this issue as exclusively comprising unforeseen and undesirable GHG emissions. In this respect it has subscribed consistently to a discourse that views biofuel-driven land-use change as little more than a carbon accounting error. The central idea being promoted by this discourse contends that the problem can be 'solved' by adding a new variable into the standard life-cycle assessments through which the GHG 
footprints of different biofuels are calculated. This variable, referred to colloquially as a landuse change 'factor', represents the central concept of the discourse. Finally, categorisations intrinsic to this discourse comprise distinctions drawn between different types of biofuels on the basis of the size of their individual land-use change 'factors', as estimated by models.

From afar, the emergence of this discourse might be explained by the presence of article 19(6) of the Renewable Energy Directive (EC, 2009), which set out a legal obligation for the European Commission to produce an impact assessment addressing only the GHG impacts of biofuel-driven land-use change by December 2010. Indeed, under this reading, it might seem entirely natural for European policy-makers to conceive of land-use change as a problem exclusively comprising unforeseen GHG emissions. On closer inspection however, the evolution of preceding and quite heated intra-Commission debates about biofuels - debates taking place between officials working for different Directorates-General - can in fact be identified as having played a critically important role in this respect.

In order to illustrate why this is the case, it is necessary first to understand the broad nature of discussions surrounding biofuels prior to the emergence of the political issue of land-use change. The testimony of one Commission official serves this purpose well:

\footnotetext{
"Biofuels policy was based on climate, on energy security and on rural development - three legs. And the thing was that whenever you - this is going back a long time now - but whenever you said "oh, but this biofuel doesn't do x", [people could] say "oh, but it does y and z"." (Interview, European Commission Official, $15{ }^{\text {th }}$ March 2011)
}

Early arguments in favour of promoting biofuel consumption in Europe's road transport sector therefore assumed a 'tripod-style' structure, emphasising in near equal measure not only the potential GHG emissions reductions that could be yielded by such a policy, but also the potential benefits for Europe's energy security and indeed rural development. The 
more restricted focus on GHG impacts that characterises debates over both biofuels and their land-use change impacts today, far from emerging automatically, can in fact be thought of as the result of highly strategic discursive activity. Specifically, this took the form of just a few Commission officials' attempts to 'reframe ${ }^{6}$ debates impinging on legislative proposals for what would eventually become the EU's Fuel Quality Directive (EC, 2009b). As one of the officials in question recounted of this strategic ploy in two separate interviews:

\begin{abstract}
"Lots of people were saying "well you need to ensure that all the attributes are good", we said "well actually the only one you can really calculate, you can really measure, is the GHG impact"." (Interview, European Commission Official, 25th June 2010)

"In the end we decided that we had to focus on one of the legs [of the tripod]. And even when we decided on the strategy, we were attacked internally by people in [our DG], who said "but you're ignoring the other impacts." And we said "it doesn't matter because you can measure GHG performance and then the rest will follow on"!" (Interview, European Commission Official, 15th March 2011)
\end{abstract}

Dominant European Commission understandings of ILUC that prevailed in the aftermath of the passing of the Renewable Energy Directive might therefore be said to have derived from this ploy on the part of officials working in one arm of the Commission, ironically undertaken at a time preceding the emergence of ILUC as a known issue. Indeed, one might even argue that any understanding of ILUC, whether as a GHG emissions-related issue or otherwise, would ultimately have been conditional upon such a narrowing in the focus of political discussions around biofuels at the European level:

"If we hadn't had the GHG [focus] we would never be talking about ILUC, because if you still had this tripod view of biofuels, we would just carry on saying... you know "palm oil's great for energy security, you know it gives you another supplier"... "and of course it's great for rural development in Indonesia"! If you didn't have the focus on GHG, where are you going to discuss ILUC?" (Interview, European Commission Official, 15th March 2011)

\footnotetext{
${ }^{6}$ Whilst the concept of 'framing' (Rein and Schön, 1991) has been influential within interpretive policy analysis, it is used here only in the colloquial sense of re-casting the basic terms of a political debate.
} 
These strategic attempts to direct particular scrutiny towards the GHG impacts of biofuel production had a very significant consequence, in that they led to the inclusion of legally binding targets for the reduction of GHG emissions embodied in all European road transport fuels by 2020 under the Fuel Quality Directive (FQD) ${ }^{7}$. This directive, moreover, complements the Renewable Energy Directive (RED) in that it shares the overall aim of bringing about more sustainable road transport practices at the European level. Consequently, far from constituting the sole cause of dominant political understandings of biofuel-driven land-use change as a carbon accounting error, article 19(6) of the RED can in fact be argued to represent one effect among many of the strategic discursive activity outlined above, undertaken by a small number of policy officials seeking to change the basic terms of wider debates surrounding biofuels in Europe. In other words, had legally binding targets not been in place to reduce overall emissions from road fuel in Europe by the year 2020, the main reasons for considering ILUC as a problem, and concomitantly the required remit of any report on the issue called for in the Renewable Energy Directive, would likely have been far less clear, and could even have been entirely different to that which was eventually dictated by article 19(6).

In short then, dominant depictions of biofuel-driven land-use change as little more than a carbon accounting error did not emerge automatically as a result of formal legal obligations contained in the Renewable Energy Directive, but in fact arose from processes firmly rooted in intricate, day-to-day social interactions taking place within the European Commission itself (ironically at a point in time preceding the emergence of land-use change as a known

\footnotetext{
7 These targets are set out in Article 7a of the FQD, which requires emissions embodied in fuels used in road vehicles to be reduced by $6 \%$ by 2020 .
} 
political issue). Arguably therefore, it is only by examining the contours of such social interactions, and in this case their manifestation in the form of piecemeal bargaining and strategising between individuals working for different Directorates-General of the European Commission, that a full explanation for the emergence of this discourse can be mounted.

Reinforcing a discourse: Policy-making 'venues', spatiality and the Brussels 'bubble'

Dominant policy discourses, however compelling, cannot perpetuate themselves of course. Instead, they must be continuously reinforced and reasserted by the actors who subscribe to them, either through speech or through action. Indeed, it is for this reason that Hajer's (1995: 44) definition of discourse includes not just "an ensemble of ideas, concepts and categorisations" that helps to provide meaning to the world around us, but also "an identifiable set of practices" through which discourses are produced and reproduced over time.

Not surprisingly, given the concern that has been expressed by a diverse range of actors over the potentially deleterious impacts of biofuel-driven land-use change (see for instance Greenpeace, 2007; EAC, 2008; Kelly, 2012; Laurance, 2007; Ravindranath et al., 2009; Royal Society, 2008; RSPB, 2008), the dominant discourse depicting this issue as a carbon accounting error has repeatedly been called into question in policy debates taking place at the European level. Yet this discourse has not been deposed, and in fact remains dominant in official documents produced by the Brussels-based policy-making community today (see for instance EC, 2012). Paying particular attention to the specific bureaucratic context within which policy debates about biofuel-driven land-use change have taken place, the following pages now move on to scrutinise the discursive practices and activities that have been used 
by policy-makers to maintain control over the dominant political account of this issue, especially since 2009 .

At one level, the dominant political discourse depicting biofuel-driven land-use change as a carbon accounting error has been reinforced through the manipulation of formal 'venues' in the European policy process designed to foster debate and discussion. Of particular significance in this respect has been the role of stakeholder meetings as an official aperture through which all actors can, theoretically at least, exert an influence over events taking place in Brussels. Ostensibly, such meetings are designed to ensure that the European Commission complies with basic principles and minimum standards for the consultation of interested parties in setting out new policy proposals, as stipulated under the Lisbon Treaty. In the case of biofuel-driven land-use change however, the conditions under which stakeholder meetings were staged have been widely denounced as far from democratic. One meeting held in September 2010, for instance, was critiqued on a number of fronts in a frank letter sent on behalf of several non-governmental organisations (NGOs) to Commissioners working at the Directorates-General for Energy (DG ENER) and Climate Action (DG CLIMA). In this letter, Commission officials who ran the meeting in question were accused of having structured the agenda "in a way that science-based policy discussions could not take place" (Hontelez, 2010). Moreover, they were further accused of: (1) a refusal to allow Joint Research Centre (JRC) scientists, flown in from Italy and at public expense, to present their scientific findings, despite explicit requests from stakeholders ${ }^{8}$; (2) the limiting of stakeholders' statements to five minutes, which caused the meeting to be shortened by several hours, as well as a refusal

\footnotetext{
${ }^{8}$ Specifically, these findings constituted a newly published report on the issue of land-use change that had been produced specifically for the purpose of facilitating more productive science-based debates on the issue at the European level (Hiederer et al., 2010).
} 
to allow open discussion in the remaining time; and (3) the prevention of several stakeholders, including non-profit organisations with a clear interest in the issue, from participating in the meeting, despite timely written requests (Hontelez, 2010).

These specific accusations, moreover, appear to confirm wider suspicions about European policy-makers' attitude to public consultation activities in general, as summarised by one disgruntled Commission official:

“[The European Commission] think it's an evil that they're forced to go through, and they don't relish it at all. Their approach to it is to try to massage the questions that they ask in such a way as to lead people to give the answers they want." (Interview, European Commission Official, 25th June 2010).

Others, however, would counter such accusations by stating that perceived biases in the way that such discussions are structured simply reflect policy-makers' desire to ensure that science is at the heart of political decision-making. As one far less disgruntled Commission official explains of public discussions in the case of biofuel-driven land-use change, for example:

'I think it's exceptionally hard to engage with the science, and the debate has reached a point where your contribution only has any credibility if you've engaged with the science. And that sets a very high bar to entry, I'm afraid. Not a bar of only the elite can do it, but a bar of only the people who are prepared to take the time to read these incredibly boring reports can do it.' (Interview, European Commission Official, 8th July 2010).

Moving beyond formal venues for debate and discussion to more informal ones too, a similar set of arguments about the importance of ensuring that scientific knowledge comes to the fore can clearly be identified in Commission officials' thinking. According to one Commission official, for instance:

"The most important input is actually scientific contributions, so [if we see] a new article in a scientific journal, we will immediately exchange and we will comment, so I believe that's the most important process." (Interview, European Commission Official, 15th March 2011) 
Unfortunately, at least in the absence of permission to carry out ethnographic research, the vast majority of these informal 'exchanges' and discussions remain impossible to observe. Some might argue that they are in any case a relatively inconsequential part of the policy process. The same official indeed goes on to remark that:

\footnotetext{
"It plays a role but a very minor role - I mean an informal lunch together will probably get me to have a look at the study which the person is offering, but not more."(Interview, European Commission Official, 15th March 2011)
}

Yet as one expert scientist with significant first-hand experience of day-to-day meetings and proceedings within the European Commission makes clear, this kind of informal exchange can nonetheless prove pivotal in placing certain ideas and arguments in policy-makers' thinking:

"Of course [the official] spends most of his time talking to lobbyists. If you go to a meeting, he
is sitting next to the [industry] representative, who is a lawyer and is a professional lobbyist for
[a biofuel company], who is extremely obnoxious and loud. And he is sitting next
to [the official] whispering in his ear through the whole meeting." (Interview, Expert Scientist,
16th April 2010). Under this reading then, discussions about biofuel-driven land-use change, whether taking place in formal venues such as stakeholder meetings or more informal 'behind the scenes' ones, are not simply structured by a desire to ensure that policy remains based upon science, but are in fact heavily influenced by the spatiality of those venues themselves, even up to the point where questions of 'who sits next to who' in meeting rooms can prove to be crucially important. Moreover, the influence of such spatiality is not only felt at the scale of Brussels. One further way in which it critically impacts upon policy developments at the European level can be found in the extent to which the policy community in Brussels as a whole isolates itself from discussions and events taking place elsewhere in Europe. As Greenpeace UK's chief scientist succinctly explains of this set of dynamics: 
'Influencing Brussels policy when you're not actually in Brussels... it's a nightmare. I mean I've tried it on several occasions and basically if you're not - there's a little bubble in Brussels and if you're not in it you don't count. And it's all very well saying you know "let's be open and democratic about all this", but actually you've got to turn up.' (Interview, Chief Scientist, Greenpeace UK, 19th July 2010).

Here then, the importance of being physically present in the city of Brussels itself is made patently clear. According to this view, unless an actor with an interest in a particular European policy takes the time to visit the physical places where policy officials hold informal and official meetings, take lunches, attend drinks receptions and the like, it will be extremely difficult for that actor to exert genuine influence over relevant policy-making processes.

To summarise, by carefully controlling the venues within which discussion relating to biofuel-driven land-use change have taken place, and by ensuring that those venues are well insulated from discussions taking place elsewhere in Europe, policy officials have succeeded in sustaining the credibility of a dominant discourse of this issue as a carbon accounting error. Moreover, this success has been achieved in spite of the widespread acceptance of such alternative discourses as legitimate outside of the specific policy venues used to stage public consultation activities in Brussels. Control over place, or what Baumgartner and Jones (1991) would describe as the choosing of a favourable 'venue' for the consideration of contentious issues, has therefore been crucial in this case because it has served to dictate the very nature of the ideas, concepts and categorisations that may be deployed in discussions about biofueldriven land-use change. Exercising control over the spaces and places of public and private debate, however insidiously, might indeed be viewed as the most effective way of influencing the precise vectors of policy development pertaining to issues as complex and controversial as this one. 
Taken together, these points lend considerable weight to the contention that "analyses of geopolitical practices must...unpack the bureaucratic context in which these practices unfold on a daily basis" (Kuus, 2011: 421). The micro-geographical settings within which actors deploy discourse and engage in discursive activity in Brussels should not be regarded merely as an inert contextual backdrop, but rather should be seen as fundamentally constitutive of the pathways through which political power is exercised in the European policy-making process.

The political impact of discourse and discursive activity: 'Placeless' knowledge?

Amongst the most obvious consequences of a narrowing in the scope of debates taking place around biofuel-driven land-use change in Brussels has been the concomitant neglect by policy-makers of a range of alternative perspectives and viewpoints on this issue. Since a group or individual may only guarantee having their voice heard by conforming to the dominant political discourse of land-use change as a carbon accounting error, arguments couched within alternative discourses are effectively stifled by policy-makers before they have even been aired. Indeed, European Commission officials' actions in this case arguably constitute a classic case of what Bachrach and Baratz (1963: 632) famously termed 'nondecision-making'; "the practice of limiting the scope of actual decision making to 'safe' issues, by manipulating... dominant community values, myths and political institutions and procedures." Of course, one might contend that, simply in order to render biofuel-driven land-use change susceptible to evaluation, calculation and intervention in the first place, policy-makers inevitably had to bring "into sharp focus certain limited aspects of an otherwise far more complex and unwieldy reality" (Scott, 1998: 11). Yet, in this instance, such a 'narrowing of vision' (ibid) has arguably had quite profound and undesirable political consequences, which it is important to reflect on here. 
Firstly, in spite of the fact that the probable geographical footprint of biofuel-driven land-use change can - at least in theory - be approximated using models, an exclusive political focus on the GHG impacts of this process has effectively rendered such knowledge irrelevant to policy-makers. Figure two, for instance, provides extremely detailed information about the probable geographical footprint of GHG emissions arising from land-use changes occurring in Brazil, as predicted by contrasting models (Marelli et al., 2011). Under a discourse that views biofuel-driven land-use change as a carbon accounting error however, it is not the precise spatial configuration of these emissions that is of interest to policy-makers, but rather the cumulative total quantity of GHG that they represent. Policy-relevant knowledge about the impacts of biofuel-driven land-use change is therefore rendered 'placeless' by this discourse in that the geography of GHG emissions does not impinge on policy-makers' assessment of their seriousness. 


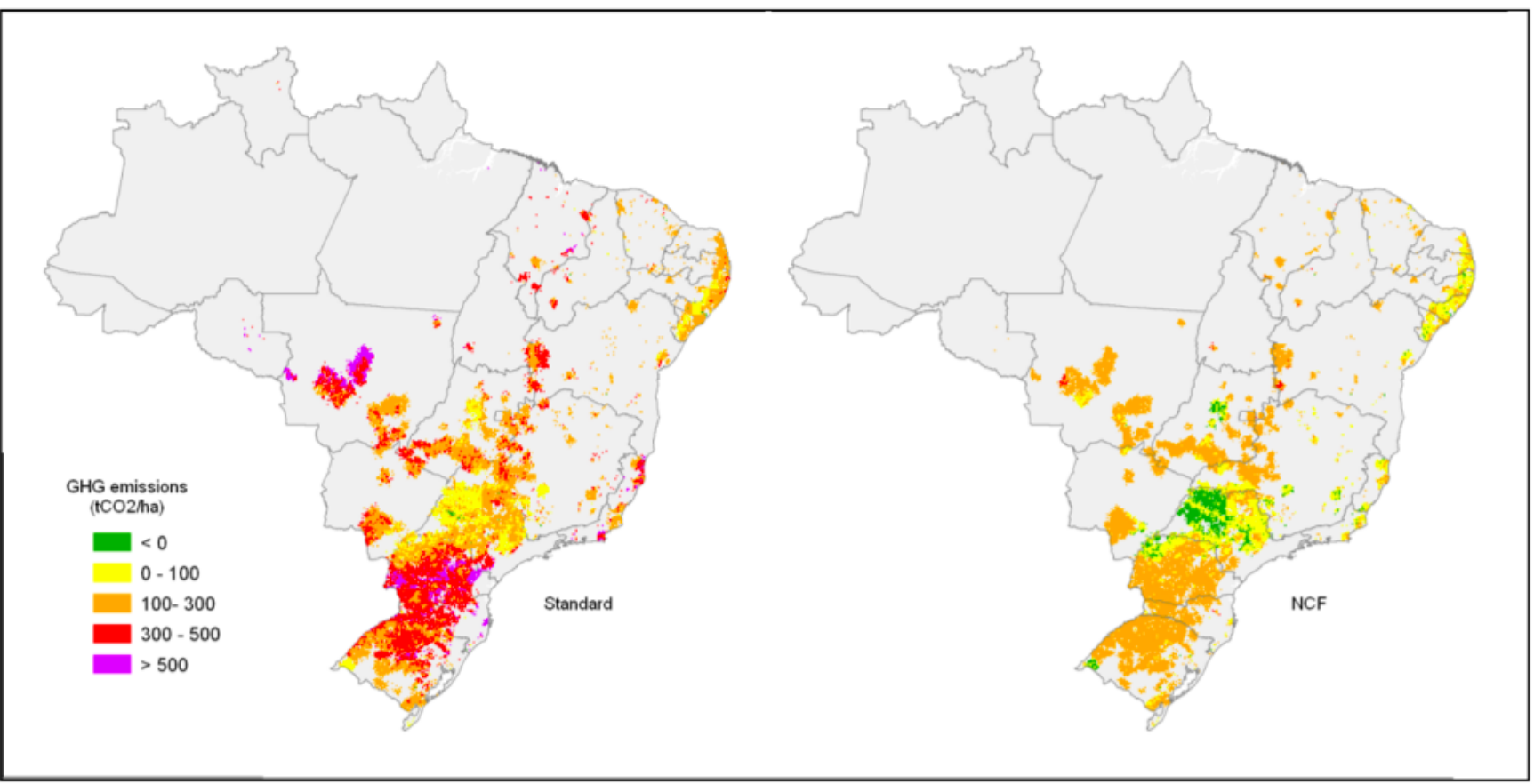

Figure 2: Diagram plotting GHG emissions arising from biofuel-driven land-use change in Brazil (Source: Marelli et al., 2011).

Moreover, by reducing the vast complexity of biofuel-driven land-use change to the status of a carbon accounting error, European policy-makers have effectively promulgated a view of land-use change in which the places affected by this process are effectively devoid of biodiversity, of people and society, and even devoid of water. 'Placelessness' therefore itself leads on to a second undesirable political consequence of policy-makers' narrow approach to biofuel-driven land-use change - the neglect of what can often be quite profound moral and ethical aspects of the problem. In the case of Brazil for instance, where biofuel production is based primarily on the cultivation of sugar cane, widespread concerns have been raised about potential impacts of land-use change upon labour standards and workers' rights (Costa, 2009). The testimony of Greenpeace UK's Chief Scientist is illustrative in this regard:

\footnotetext{
'In the case of [Brazilian sugar cane], I have to be fairly careful to say that environmentally it can be sustainable. I'm not sure it can be considered socially sustainable. It's essentially pretty bloody awful work; I mean I would hesitate to say slave labour, but I'm not sure the labour standards are at all anything that we would like to encourage.' (Interview, Chief Scientist, Greenpeace UK, 19th July 2010).
} 
In the case of corn ethanol production taking place in American Midwest, by contrast, increased demand for biofuels sits in direct competition with biodiversity conservation or water quality protection initiatives, and is also viewed as partly responsible for increased levels of eutrophication around the Mississippi delta. As one eminent environmental biologist working at Cornell University explained:

\begin{abstract}
'We have conservation lands we've set aside to improve biodiversity in the mid-west farming area, and also to provide water quality protections, and we're losing those conservation lands; they're being planted back to corn because of the huge economic incentives to do so that are fuelled by ethanol.' (Interview, Environmental Biologist, 2oth July 2010).
\end{abstract}

Finally, even within Europe, concerns have been raised over the potential impact that landuse change might exert upon biodiversity. The Royal Society for the Protection of Birds (RSPB), for instance, contends that the turning over of set-aside land to agricultural production will inevitably entail the loss of "important feeding and nesting grounds for birds" such as the charismatic but declining little bustard (RSPB, 2008: 11).

Each of these three cases highlights unique ways in which current assessments of the GHG emissions arising from biofuel-driven land-use change overlook an array of potential wider impacts. Yet, in spite of the fact that these impacts are all widely acknowledged as important by a range of actors, they remain excluded from discussion in Brussels by the hegemonic discourse of carbon accounting and GHG emissions. As one biofuels campaigner working in the Brussels office of prominent non-governmental organisation (NGO) Birdlife International therefore summarises:

'There is a quite terrifying moral aspect to [land-use change] which is not present in the debate and to be honest I mean this level of argument you are not even able to make it in Brussels because otherwise you are seen as a sort of green loony. And that's why we are reduced to discussing modelling and the assumptions here and the assumptions there... which, honestly I find quite depressing.' (Interview, 29th July 2010). 
In short then, under the current dominant discourse depicting this issue as a mere carbon accounting error, place-specific accounts of the wider impacts that might potentially be felt from biofuel-driven land-use changes 'on the ground', whether by humans, plants or animals, have been effectively elided. The treatment of biofuel-driven land-use change by European policy-makers can therefore be said to epitomise a far more widespread oversight characteristic of many developed countries' approach to the problem of climate change as a whole, identified by van der Horst and Evans (2010) as a 'missing political ecology of carbon'. As these authors write of practices seeking to derive energy from biomass, "crops have to be grown somewhere, with a distinct political and cultural heritage, and a distinct physical environment" (ibid: 190). To overlook this so-called political ecology of carbon is both to elide the place-specific nature of processes contributing to climate change, and in many cases also to overlook what are fundamentally moral and ethical issues arising from political attempts to deal with this issue.

\section{Conclusions}

From a discursive-institutionalist perspective, this paper has analysed interactions between discourse, discursive activity and place in the context of European-level debates about biofuel-driven land-use change. Controversy surrounding this problem emanates both from the variety of potentially deleterious impacts that it might bring about, and - at least in the case of indirect land-use change - from the fact that it is not possible to directly observe those impacts in the real world. In the face of such complexity and uncertainty, European policymakers have sought to operationalize the problem of biofuel-driven land-use change and make it 'knowable' by advancing a discourse that depicts the issue as exclusively comprising unforeseen and undesirable greenhouse gas (GHG) emissions. Both in seeking to establish 
this discourse as dominant, and then later in seeking to maintain its legitimacy in the face of alternative, competing accounts of the problem, Commission officials' have engaged in persuasive discursive activity aimed at strictly controlling what can and cannot be said about land-use change in the spaces and places playing host to official debates addressing the issue. Moreover, this activity has been heavily conditioned by the place-specific characteristics of Brussels itself, as a unique bureaucratic setting. Specifically, complex social interactions and bargaining between officials working for different Directorates-General, the ability to exercise control over formal and informal 'venues' for policy discussion, questions of who sits next to who in meeting rooms and elsewhere, and finally the insular nature of Brussels itself, have all played important roles in determining exactly how political power has been exercised in this field of policy at the European level. Such dynamics, moreover, operate both at the microscale (where certain venues only permit arguments that subscribe to a particular, dominant discourse) and at the macro-scale (where a physical presence in Brussels is essential if one wishes to gain the ear of relevant policy officials).

Two undesirable political effects of Commission officials' subscription to a discourse depicting biofuel-driven land-use change as a carbon accounting error have been the neglect not just of place-specific knowledge about this process' impacts, but also concomitantly of many profoundly moral and ethical dimensions of the issue. In short, European policymakers' attempts to render land-use change 'knowable' have involved a rejection of the inherently geographical nature of this process, forcing actors with concerns about its placespecific, local implications to either abandon these components of their arguments, or face being ignored altogether. By exercising discursive control over the spaces and places of official policy discussion, Commission officials have therefore insulated the policy-making 
process from competing, alternative discourses around the issue of biofuel-driven land-use change, even though, at least outside of Brussels, many of these discourses have long been regarded as legitimate and important.

Overall, this paper has sought to demonstrate the critical importance of studying the interactions of place and discourse in the European environmental policy-making process. Following Merje Kuus (2011), it therefore concludes by arguing that future geographical analyses of environmental governance, both within Europe and beyond, should pay far greater attention to the ways in which the fabric of policy-making is constituted in specific places. Critical questions to be asked by geographers in the future might indeed address the precise spatial configuration of day-to-day, social interactions and relationships that play out in particular bureaucratic contexts, as well as their impact on the success or failure of different political strategies and attempts to exercise power over the policy process itself. Not dissimilarly, geographers might also productively pay greater attention to the ways in which particular knowledge regimes and discourses surrounding a policy problem reflect the places in which they are produced, articulated and reinforced, rather than the places to which they ultimately pertain. If conducted effectively, such analyses promise to yield rich insights into the precise mechanisms through which political disagreement is managed, negotiated and settled in advanced modern democracies, especially in the context of issues characterised by profound complexity and uncertainty, such as that evident in the case of biofuel-driven landuse change. 


\section{References}

Al-Riffai, P., Dimaranan, B. and Laborde, D. 2010. Global Trade and Environmental Impact Study of the EU Biofuels Mandate, Final Report, March 2010. International Food Policy Research Institute, Washington, D.C.

Bachrach, P. and Baratz, M.S. 1963. 'Decisions and Non-decisions: An Analytical Framework.' The American Political Science Review 57(3): 632-642.

Bailey, R. 2008. Another Inconvenient Truth: How biofuel policies are deepening poverty and accelerating climate change. Oxfam Briefing Paper 114, Oxfam International, Oxford.

Baumgartner, F.R. and Jones, B.D. 1991. 'Agenda Dynamics and Policy Subsystems.' The Journal of Politics 53(4): 1044-1074.

Baumgartner, F.R. and Jones, B.D. 2009. Agendas and Instability in American Politics, $2^{\text {nd }}$ Edition. The University of Chicago Press, Chicago, IL.

Birdlife International, European Environmental Bureau and Transport \& Environment. 2010. Bioenergy: A Carbon Accounting Time Bomb. Birdlife International, Brussels.

Bowyer, C. 2010. Anticipated Indirect Land Use Change Associated with Expanded Use of Biofuels and Bioliquids in the EU - An Analysis of the National Renewable Energy Action Plans. Institute for European Environmental Policy, London.

Clift, R. and Mulugetta, Y. 2007. 'A Plea for Common Sense (and Biomass).' The Chemical Engineer, October 2007: 24-26.

Costa, P.T.M. 2009. Fighting Forced Labour: The Example of Brazil. International Labour Office, Geneva.

Cresswell, T. 2004. Place: A Short Introduction. Blackwell, Oxford.

Danielsen, F., Beukema, H., Burgess, N.D., Parish, F., Brühl, C.A., Donald, P.F., Murdiyarso, D., Phalan, B., Reijnders, L., Struebig, M. and Fitzherbert, E.B. 2008. 'Biofuel plantations on forested lands: Double jeopardy for biodiversity and climate.' Conservation Biology 23(2): 348-358.

Dunlop, C.A. 2010. 'The temporal dimension of knowledge and the limits of policy appraisal: biofuels policy in the UK.' Policy Sciences 43(4): 343-363.

EAC. 2008. Are biofuels sustainable? First report of the session 2007-2008, HC 76-1. House of Commons Environmental Audit Committee. The Stationery Office, London.

EC. 2003. 'Directive 2003/30/EC of the European Parliament and of the Council of $8^{\text {th }}$ May 2003 on the promotion of the use of biofuels or other renewable fuels for transport.' Official Journal of the European Union L123, 42-46, $17^{\text {th }}$ May. European Commission, Brussels. 
EC. 2009a. Directive 2009/28/EC of the European Parliament and of the Council of 23rd April 2009 on the promotion and use of energy from renewable sources and amending and subsequently repealing Directives 2001/77/EC and 2003/30/EC. Official Journal of the European Union L140, 16-62.

EC. 2009b. Directive 2009/30/EC of the European Parliament and of the Council of $23^{\text {rd }}$ April 2009 amending Directive 98/70/EC as regards the specification of petrol, diesel and gasoil and introducing a mechanism to monitor and reduce greenhouse gas emissions and amending Council Directive 1999/32/EC as regards the specification of fuel used by inland waterway vessels and repealing Directive 93/12/EEC. Official Journal of the European Union, L140: 88-113.

EC. 2010. COM (2010) 811 final: Report from the Commission on indirect land-use change related to biofuels and bioliquids. European Commission, Brussels.

EC. 2012. Commission staff working document: Executive Summary of the Impact Assessment on Indirect Land-Use Change related to biofuels and bioliquids. SWD (2012) 344 final. European Commission, Brussels.

Fargione, J., J. Hill, D. Tilman, S. Polasky, and P. Hawthorne. 2008. 'Land Clearing and the Biofuel Carbon Debt.' Science 319(5867): 1235-1238.

Friends of the Earth Europe. 2007. Agrofuels: Fuelling of fooling Europe? Press Release, available at: http://www.foe.co.uk/resource/briefings/agrofuels_fuelling_or_fool.pdf [Accessed 14 $4^{\text {th }}$ June 2012].

Greenpeace. 2007. How the palm oil industry is cooking the climate. Greenpeace International, Amsterdam, NL.

Hajer, M.A. 1995. The Politics of Environmental Discourse. Oxford University Press, Oxford.

Hajer, M.A. 2005. 'Coalitions, Practices and Meaning in Environmental Politics: From Acid Rain to BSE' in Howarth, D. and Torfing, J. (eds.) Discourse Theory in European Politics: Identity, Policy and Governance. Palgrave Macmillan, Basingstoke.

Heclo, H. 1974. Modern Social Politics in Britain and Sweden. Yale University Press, New Haven, CT.

Hiederer, R., Ramos, F., Capitani, C., Koeble, R., Bludjea, V., Gomez, O., Mulligan, D. and Marelli, L. 2010. Biofuels: A new methodology to estimate GHG emissions from global land use change. European Commission Joint Research Centre, Institute for Environment and Sustainability and Institute for Energy, Ispra, Italy.

Hontelez, J. 2010. Complaint against management of $17^{\text {th }}$ September 2010 Stakeholders Meeting on EU Biofuels Policies. $27^{\text {th }}$ September 2010. Available at: http://www.clientearth.org/reports/ce-v-ec-reply-annexes-2-march-2011.pdf [Accessed 14th June 2012]. 
Kelly, R. 2012. The Hunger Grains. Oxfam Briefing Paper 161, 17th September 2012. Oxfam GB, Oxford.

Koh, L. P. and Ghazoul, J. 2008. 'Biofuels, biodiversity and people: Understanding the conflicts and finding opportunities.' Biological Conservation 141: 2450-2460.

Kutas, G., Lindberg, C. and Steenblik, R. 2007. Biofuels: At What Cost? Government Support for Ethanol and Biodiesel in the European Union. Global Studies Initiative, International Institute for Sustainable Development, Geneva, SUI.

Kuus, M. 2011. "Bureaucracy and Place: Expertise in the European Quarter." Global Networks $11(4): 421-439$.

Laurance, W.F. 2007. 'Switch to Corn Promotes Amazon Deforestation.' Science 318: 1721.

Matondi, P.B., Havnevik, K. and Beyene, A. (eds.) 2011. Biofuels, Land-Grabbing and Food Security in Africa. Zed Books, London.

Marelli, L., Ramos, F., Hiederer, R. and Koeble, R. 2011. Estimate of GHG emissions from global land-use change scenarios. Presentation delivered to a stakeholder meeting on indirect land-use change resulting from biofuel production, Brussels, $18^{\text {th }}$ November 2011.

Mawdsley, E. 2012. From Recipients to Donors: Emerging Powers and the Changing Development Landscape. Zed Books, London.

Milton, K. (ed.) 1993. Environmentalism: The View from Anthropology. Routledge, London.

Mitchell, D. 2008. A Note on Rising Food Prices. Policy Research Working Paper 4682, Development Prospects Group, World Bank, Washington, D.C.

Palmer, J. 2010. 'Stopping the unstoppable? A discursive-institutionalist analysis of renewable transport fuel policy.' Environment and Planning C: Government and Policy 28(6): 9921010.

Palmer, J. 2012. 'Risk governance in an age of wicked problems: Lessons from the European approach to indirect land-use change.' Journal of Risk Research 15(5): 495-513.

Ravindranath, N.H, Manuvie, R., Fargione, J., Canadell, J.G., Berndes, G., Woods, J., Watson, H. and Sathaye, J. 2009. 'Greenhouse gas implications of land use and land conversion to biofuels crops', in Howarth, R.W. and Bringezu, S. (eds.) Biofuels: Environmental Consequences and Interactions with Changing Land Use. Cornell University, Ithaca NY, USA, pp. 111-125.

Rice, T. 2010. Meals per gallon: The impact of industrial biofuels on people and global hunger. Action Aid, London.

Royal Society. 2008. Sustainable Biofuels: Prospects and Challenges. Policy Document o1/o8. 
RSPB. 20o8. A Cool Approach to Biofuels. Royal Society for the Protection of Birds. Available at: http://www.rspb.org.uk/Images/Biofuels_tcm9-187450.pdf [Accessed $14^{\text {th }}$ June 2012].

Schmidt, V.A. 2008. 'Discursive Institutionalism: The Explanatory Power of Ideas and Discourse.' Annual Review of Political Science 11: 303-326.

Schmidt, V.A. 2011. 'Speaking of change: Why discourse is key to the dynamics of policy transformation.' Critical Policy Studies 5(2): 106-126.

Schmidt, V.A. and Radaelli, C.M. 2004. 'Policy Change and Discourse in Europe: Conceptual and Methodological Issues.' West European Politics 27(2): 183-210.

Schön, D.A. \& Rein, M. 1994. Frame Reflection: Toward the Resolution of Intractable Policy Controversies. Basic Books, New York.

Scott, J.C. 1998. Seeing Like A State: How Certain Schemes to Improve the Human Condition Have Failed. Yale University Press, New Haven, CT.

Searchinger, T., R. Heimlich, R. A. Houghton, F. Dong, A. Elobeid, J. Fabiosa, S. Tokgoz, D. Hayes, and T-H. Yu. 20o8. 'Use of U.S. Croplands for Biofuels Increases Greenhouse Gases Through Emissions from Land-Use Change.' Science 319(5867): 1238-1240.

Searchinger, T., S. P. Hamburg, J. Melillo, W. Chameides, P. Havlik, D. M. Kammen, G. E. Likens, R. N. Lubowski, M. Obersteiner, M. Oppenheimer, G. P. Robertson, W. H. Schlesinger, and G. D. Tilman. 2009. 'Fixing a Critical Climate Accounting Error.' Science 326: 527-528.

The Times. 2008. 'Rush for biofuels threatens starvation on a global scale', $7^{\text {th }}$ March 2008.

van der Horst, D. and Evans, J. 2010. 'Carbon claims and energy landscapes: Exploring the political ecology of biomass.' Landscape Research 35(2): 173-193.

Vermeulen, S. And Cotula, L. 2010. 'Over the heads of local people: Consultation, consent, and recompense in large scale land deals for biofuel projects in Africa.' The Journal of Peasant Studies 37(4): 899-916.

Woods, J. 2009. Bioenergy and indirect land-use change. Presentation delivered at UNEP, IPIECA, EPFL and RSB indirect land-use change conference, Lausanne, Switzerland, 9th $\quad$ November 2009 Available at: http://rsb.epfl.ch/files/content/sites/rsb2/files/Biofuels/Regional\%2oOutreaches\%20\& \%20Meetings/2009/Nov\%202009\%2oiLUC\%20Conference/Workman_Woods_ILUC_I PIECA_ognovoga\%20-\%2oFinal.pdf [Accessed 14th June 2012]. 